\title{
FORMATION PROCESS OF COASTAL ECOREGIONS IN RELATION TO QUATERNARY GEOLOGICAL ACTIVITIES IN BINH THUAN PROVINCE
}

\author{
Duong Thi Thanh Xuyen ${ }^{1}$, Nguyen Van Tuan ${ }^{2}$, Tran Nghi ${ }^{3 *}$, \\ Nguyen Dinh Thai ${ }^{3}$, Nguyen Thi Tuyen ${ }^{3}$ \\ ${ }^{1}$ Vietnam Environment Administration \\ ${ }^{2}$ Institute of Geosciences and Mineral Resources, MONRE \\ ${ }^{3}$ Hanoi University of Science, $V N U$ \\ E-mail: tranhnghi@gmail.com
}

Received: 26-7-2017

\begin{abstract}
Endogenous and exogenous geological processes have divided the coastal zone of Binh Thuan province into four typical ecological zones: Late-Holocene plain ecoregion with rivermarine origin which is distributed between coastal sand dunes and the foot/base of the Truong Son mountains, coastal sand dune ecoregion $0-150 \mathrm{~m}$ high, tidal ecoregion $0-5 \mathrm{~m}$ deep, bottom-sediment ecoregion 5- $25 \mathrm{~m}$ deep and the ancient shoreline ecoregion $25-30 \mathrm{~m}$ deep. The plain ecoregion and the subterranean bays were formed mainly due to the subsidence motion and the sedimentation in relation to the sea level change in the Holocene. The sand dune ecoregion was the result of the evolution process of five sand formation cycles in relation to five cycles of sea level change in the Quaternary due to the effects of five glacial cycles and interglacier Gunz/GM, Mindel/MR, Riss/R- $\mathrm{W}_{1}, \mathrm{Wurm} / \mathrm{W}_{1}-\mathrm{W}_{2}$ and Wurm2/Flandrian transgression.
\end{abstract}

Keywords: Coastal ecoregion, Binh Thuan province, Quaternary geological activity.

\section{INTRODUCTION}

Prior to 1975, research on geological and geomorphological conditions in Binh Thuan province was of little interest except a research by Fontaine (1972) on the Quaternary formations in the South Central Coast. In that research, Fontaine discovered the Neogenic sandstone and the $15 \mathrm{~m}$ high sea floor on the coast of Khanh Hoa.

From 1975 up to now, there have been many thematic studies and works on Quaternary geological mapping on a scale 1:50,000 in Ninh Thuan and Binh Thuan $[1,2]$. In 1978, Le Duc An studied the geology and the geomorphology of Phan Thiet area and found tektite of 700,000 years BP. At the same time, Le Duc An also established the Phan Thiet formation of Middle Pleistocene $\left(\mathrm{Q}_{1}{ }^{2} \mathrm{pt}\right)$.

Study on ilmenite mineral sand in Binh Thuan has been done by many authors such as Dao Thanh Binh (1983), Nguyen Thanh Binh (1988), Nguyen Kim Hoan and Nguyen Bieu (1985). However, it was not until 1990 that the Quaternary geological mapping on a scale 1:50,000 and new thematic studies were implemented synchronously. Nguyen Van Cuong et al., (2001) conducted the geological mapping on a scale 1:50,000 and searched for mineral group Ham Tan - Con Dao. Hoang Phuong, Ma Cong Co and Tran Nghi (1977) carried out a geological mapping on a scale 1:50,000 in Phan Thiet [3-5]. Both Nguyen Van 
Cuong and Hoang Phuong established the Phan Thiet red sand stratum column without Early Pleistocene $\left(\mathrm{Q}_{1}{ }^{1}\right)$. The age $\left(\mathrm{Q}_{1}{ }^{2-3}\right)$ of the Phan Thiet formation is conventional while the absolute age has not been established yet.

From 2012 to 2014, the authors conducted surveys and studied in detail 4 sections (fig. 2, 3a, 4a). 100 sand samples in 4 sections collected and processed to analyze the parameters: Particle size, mineral compositions, quartz content, roundness of debris and basic chemical compositions. The authors also conducted 20 boreholes drilled by the General Department of Geology under the prospecting titanium project in Binh Thuan province.

Based on the integrated analysis method of documents, combined with survey methods, and outdoor studies, Binh Thuan's coastal zone is divided into 4 specific ecological zones.

In 2000 - 2001, Tran Nghi, Colin Wallace [6], Brian Jone (Australia) in the topic "Research on the age of quartz fluorescence heat, origin and conditions of red sand creation in Phan Thiet" achieved new results in comparison to previous researches. The authors found an Early Pleistocene red sand cycle $\left(\mathrm{Q}_{1}{ }^{1}\right)$ under the "laterization sand" layer containing the sharp edged tektite of 700,000 years old PB.

The article is aimed to describe the causal relationship between endogenous and exogenous geological processes with terrain, geomorphology and terrestrial ecoregions and coastal wetlands in relation to sea level change and tectonic movement. The coastal area of Binh Thuan expresses four characteristic ecoregions that can be realized very clearly in space from shore to sea.

The river-marine ecoregion distributed in the low terrain $(\leq 5 \mathrm{~m}$ above the sea level) is relatively flat, which is intercalated between the high mountain terrain in the west of the Truong Son mountain and coastal sand dunes.

The tidal ecoregion which is mainly composed of sand formed by wave and tide is the bridge between mainland and sea lying between the rising sea level due to storm and the depth of $5 \mathrm{~m}$. Therefore, this ecoregion has 3 terrains: a) The beach terrain is high and not tidally submerged where tourists can take a rest or sunbathe; b) The tidal flat lies in the limits of the low tide and the high tide; c) The low tide terrain is relatively gentle and always submerged, which is the main space where tourists bathe and swim.

The bottom sediment ecoregion is distributed from the water depth of $5 \mathrm{~m}$ to $25 \mathrm{~m}$. Major sediments are sand, sand and muddy sand inheritedly formed in three phases of sea level change: a) Flandrian transgression $\left(\mathrm{Q}_{2}{ }^{1-2}\right)$; b) Middle and Late Holocene sea-level fall $\left(\mathrm{Q}_{2}{ }^{2-3}\right)$ and c) Modern sea-level rise $\left(\mathrm{Q}_{2}{ }^{3}\right)$.

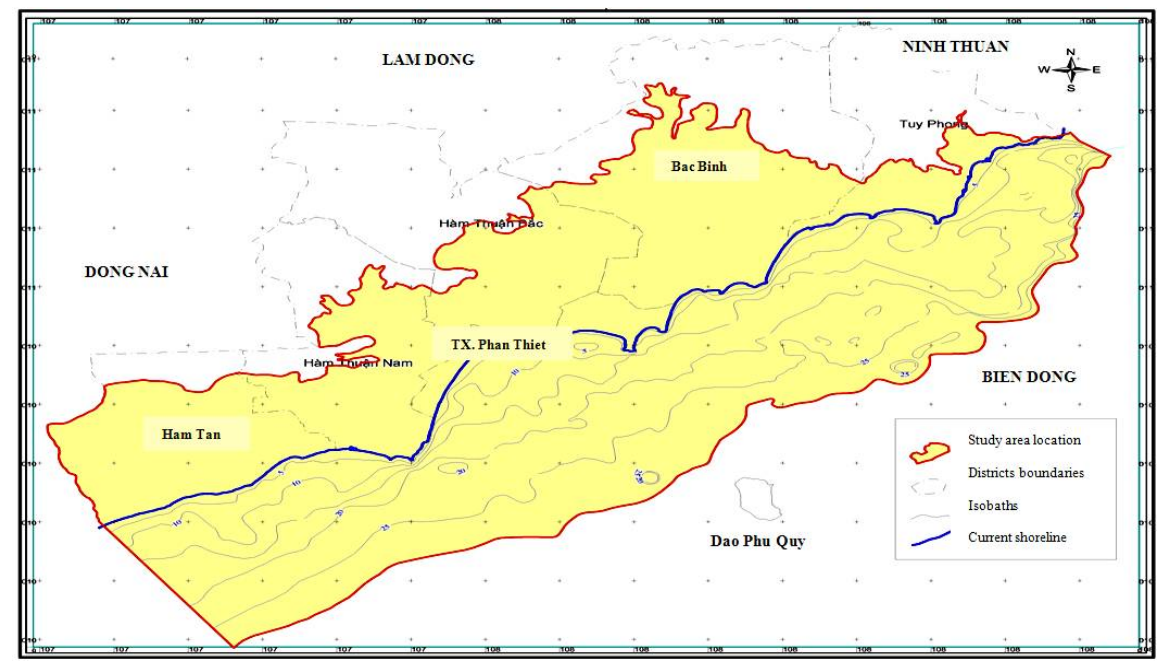

Fig. 1. Location of study area 


\section{RESULTS AND DISCUSSION}

The formation of four ecological zones in relation to the history of Quaternary geological development of the coastal zone of Binh Thuan province

The coastal area of Binh Thuan province can be divided into four horizontal ecoregions (perpendicular to the modern shoreline): plain

The ecoregion of the fluvial-marine narrow

The fluvial-marine narrow plains of Late Holocene $\left(\mathrm{am} \mathrm{Q}_{2}{ }^{3}\right.$ ) are distributed along the Truong Son mountain and adjacent to the dunes. These plains have three distinct origins that are undivided and distributed at two different terrain levels: (i) Higher flood plain of Quao, Luy, Cai and Ca Ti rivers; (ii) The lower flood plain of the above rivers is of Late Holocene and (iii) The modern fluvial-marine sediments is distributed in estuaries. The beginnings of the cycles are coarser sediment and gravel beds belonging to the lowstand systems tract (LST). The endings of the cycles are the transgressive systems tract (TST) and highstand systems tract (HST). Quaternary sedimentary plains of Binh Thuan province are very thin ( 1 - $20 \mathrm{~m}$ thick) covering bed rock which is Quaternary basement. Quaternary basement has rough terrain and rises high near the surface of the plain. This is the direct reason why Binh Thuan province does not have Quaternary water tank.

\section{Ecoregion of coastal sand dunes}

The coastal sand dunes of Binh Thuan Province are the product of five sand cycles in association with five cycles of sea-level rise and fall [7]. Each sand cycle has three overlapping layers: (1) The lower one is sand created by the wind (mv) formed during the lowstand systems tract (LST); (2) The middle one is the sand of the coastal sandy barrier bar (m) formed in the transgressive systems tract (TST); (3) The upper one is sand created by the wind (mv) formed in the highstand systems tract (HST) (fig. 2, 3a, 4a).

Red sand is easy to recognize by the unique red wine colour, which is strongly geologically and ecologically impressive. Along the coastline from Tuy Phong, Ham Thuan Bac, Ham Thuan Nam, Phan Thiet city, Ham Tan and Phu Quy islands, the red sand is distributed in a vast area and various heights from $0 \mathrm{~m}$ to $150 \mathrm{~m}$. From the southern tidal areas of the city of Phan Thiet to the high plateaus as the Luy river, Mui $\mathrm{Ne}$, there are clearly spreading seafloors. Red sand is usually thought to have a different age compared to non-red sand. In fact, it is not so simple because the red sands themselves are complicated, there is a change in the origin of colour, granularity, and sedimentary composition in the cross section (time) and in space.

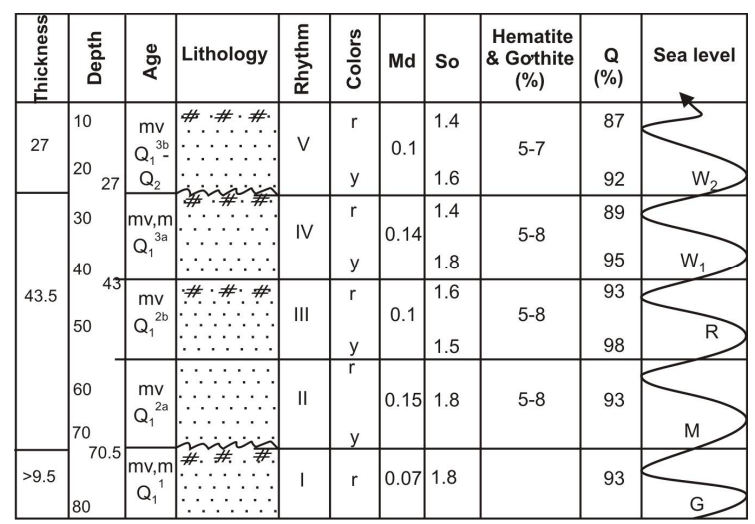

Fig. 2. Sequence stratigraphy column of $\mathrm{BH}$ PT-1 at the Phan Thiet airport

It is possible to consider some typical sections of coastal sandy sediments of Binh Thuan province as follows:

Cross section at Phan Thiet airport: Phan Thiet red sandy formation is distributed to the sea with the height of $80 \mathrm{~m}$. The 1-PT borehole in the depth of $79 \mathrm{~m}$ shows that this layer also has a thickness of $79 \mathrm{~m}$ and covers a sorted multi sand mineral sediment and weakly rounded grinding layer. Grain size varies from coarse $(0.14-0.15 \mathrm{~mm})$ to fine $(0.09-1.1 \mathrm{~mm})$ corresponding to the beginning and the end of each cycle (fig. 2). The aforementioned sand ranges are well to medium sorted (So $=1.4$ 1.8). Quartz content is quite high which accounts for $89-95 \%$. The results of rongen analysis of particle size less than $0.1 \mathrm{~mm}$ give hematite and gothite content of $5-8 \%$ (fig. 2). 
Thus, Phan Thiet's red sand originated from the ocean, belonging to the acient coastal sand dune facies. There are three generations of overlapped sand dunes corresponding to three color ranges, the boundary among them is the more ancient formed abrasive sand dyke. The sand dikes formed in the sea-level rise cycles (by the influence of the inter-glacial cycle), lying on the raised ridges of the foundations making up a large lagoon in the west (Van Lam - Muong Man) which developed from the Early Pleistocene to the Holocene (fig. 1).

Cross section in Hon Rom area (North of Mui Ne): From the bottom to top, there are the following sand layers: (1) Dark red sandstone has a hard laterite surface similar to a iron hat. Lateritic shell of $5-15 \mathrm{~cm}$ thick is due to the accumulation of iron glue on the surface of the capillary action by the long-term permeability of alternating groundwater and surface water between reduction $\left(\mathrm{Fe}^{2+}\right)$ and oxidation $\left(\mathrm{Fe}^{2+} \rightarrow\right.$ $\left.\mathrm{Fe}^{3+}\right)$. Tektite edge on the laterite surface allows identification of this red sandstone layer over the age of more than 700,000 years (Early Pleistocene); (2) The second sand layer (60 m thick) from the bottom. White sand mixed with yellow sand, medium-sized mixed with largesized granules laying horizontal wave, good adhesion can be taken a thin layers. Yellow mixed red sand horizontal layering and horizontal layer wave. Homogeneous red sand forms the structure of alternating block oblique diagonal wave. There are two layers of colour: white sand mixed with red sand; Light red, dark red sand forms horizontal, horizontal and diagonal cross sections intermingled in massive blocks of sand mass; (3) The third sand layer (10 - $15 \mathrm{~cm}$ thick) with fine yellow sand, fine filter, block structure is distributed at the height of $75-80 \mathrm{~m}$, containing many fine rounded andesite pebbles (fig. 2). This is the typical weathering stratigraphic profile of each sand rhythm: from the spotted sand zone (bottom) to the laterite sand zone on the surface or homogeneous dark red sand. Three sand layers corresponding to three generations of sandy barrier bar formed in three transgressive cycles: The late Early Pleistocene $\left(\mathrm{Q}_{1}{ }^{1}\right)$; The late Middle Pleistocene $\left(\mathrm{Q}_{1}{ }^{2}\right)$; The late Late Pleistocene $\left(\mathrm{Q}_{1}{ }^{3 \mathrm{~b}}\right)$.

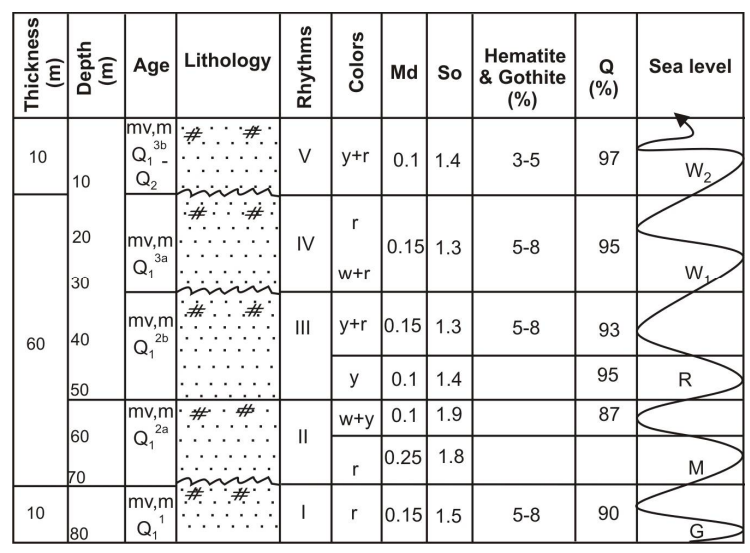

Fig. 3a. Sequence stratigraphic column at the Ho Rom (North of Mui Ne) [Founder: Duong Thi Thanh Xuyen, Nguyen Van Tuan, Tran Nghi]

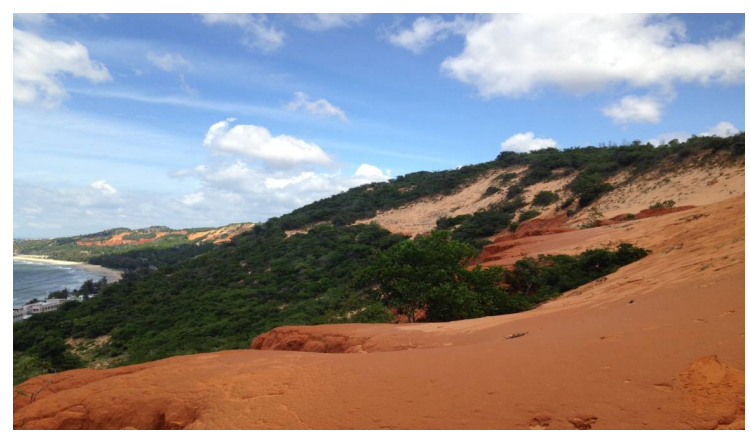

Fig. 3b. Sandy barrier bar along the coast (left) and sand dunes (right) at the Hon Rom (Mui

$\mathrm{Ne}$ ) [Photo by Nguyen Van Tuan, (2016)]

The cross section in Tien stream (Mui $\mathrm{Ne}$ ): Suoi Tien (Mui Ne) originates from the red sand piedmonts that pour into the sea, causing constant slashing of the side walls to reveal the bizarre white sand eroded cleft. From $70 \mathrm{~m}$ downwards, the following sedimentary layers are encountered: (1) From 70 - 15 m: Homogeneous tiny-grain, fine-filtered red sand with block structure, then the yellow sand $(5 \mathrm{~m}$ thick) and finally the fine white, tiny-grain, well-sorted sand ( $2 \mathrm{~m}$ thick). This layer has an absolute age of 73,000 years; (2) From 15 $5 \mathrm{~m}$ : Grey sand containing angular tektite gravel, the face is usually like weakly bonded polymictic sandstone. Under the polarized microscope, $3 \%$ plagioclase and $2 \%$ potassium feldspar can be determined. The materials that bond the grain are mainly siliceous carbonate 
and calcium sulphate. The layer has an absolute age of over 181,000 years BP. (3) From 5 $1 \mathrm{~m}$ : Concrete grey white sand. The grain is relatively well bonded by lime and silica but has not gone through the rock formation process. The sediment is formed in the ancient coastal proluvial transition environment; (4) From a depth of $0-2.7 \mathrm{~m}$, there is a layer of grey pebbles of Quaternary sediments which overlies on weathered erosive surface of basalt. Thus, this section has two typical sedimentary layers. The firsl layer 1 is in the age of Early Pleistocene starting with pebbles (regression) (fig. 4b), ending with gray sand (transgression), $27 \mathrm{~m}$ thick. The second layer begins with grey white sand and ends with red sand and belongs to the coastal sand dune of the late Middle Pleistocene (transgression), $70 \mathrm{~m}$ thick (fig. 4c).

\begin{tabular}{|c|c|c|c|c|c|c|c|c|c|c|c|}
\hline \multirow{2}{*}{ 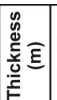 } & \multirow[b]{2}{*}{ 总 } & \multicolumn{2}{|c|}{ Age } & \multirow[b]{2}{*}{ Lithology } & \multirow{2}{*}{ 足 } & \multirow[b]{2}{*}{ 흥 } & \multirow[b]{2}{*}{ Md } & \multirow[b]{2}{*}{ So } & \multirow{2}{*}{$\begin{array}{c}\text { Hematite } \\
\text { \& Gothite } \\
(\%)\end{array}$} & \multirow[b]{2}{*}{$\begin{array}{c}Q \\
(\%)\end{array}$} & \multirow[b]{2}{*}{ Sea level } \\
\hline & & 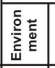 & ка & & & & & & & & \\
\hline & $\mid \begin{array}{l}10 \\
20\end{array}$ & $\begin{array}{c}m v, m b \\
Q_{1}, \\
Q_{2}\end{array}$ & & & V & & & 1.4 & & & \\
\hline 62 & $\begin{array}{l}30 \\
40\end{array}$ & $\left|\begin{array}{c}m v, m \\
\mathrm{Q}_{1}^{3 a}\end{array}\right|$ & 73 & & IV & $r$ & 0.22 & 1.3 & $5-7$ & 95 & \\
\hline & 60 & $\left|\begin{array}{c}\mathrm{mv}, \mathrm{m} \\
\mathrm{Q}_{1}^{2 \mathrm{2b}}\end{array}\right|$ & & & III & $\begin{array}{l}y \\
w\end{array}$ & 0.2 & $1.2^{\circ}$ & & 97 & \\
\hline 8 & 70 & & $>181$ & & & $w-g$ & 0.25 & 1.6 & & & \\
\hline 20 & 80 & $\mid \begin{array}{c}m v, m \\
\mathrm{Q}_{1}^{2 a}\end{array}$ & & d & ॥ & $g$ & $\begin{array}{l}0.5 \\
0.02 \\
\end{array}$ & & & & \\
\hline 10 & 100 & $\begin{array}{c}m \mathrm{mv}, \mathrm{m} \\
\mathrm{Q}_{1}{ }^{1}\end{array}$ & & 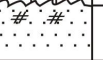 & 1 & & & & & & \\
\hline
\end{tabular}

Fig. 4a. Sequence stratigraphic column at the Mui Ne area [Founder: Duong Thi Thanh Xuyen, Nguyen Van Tuan, Tran Nghi]

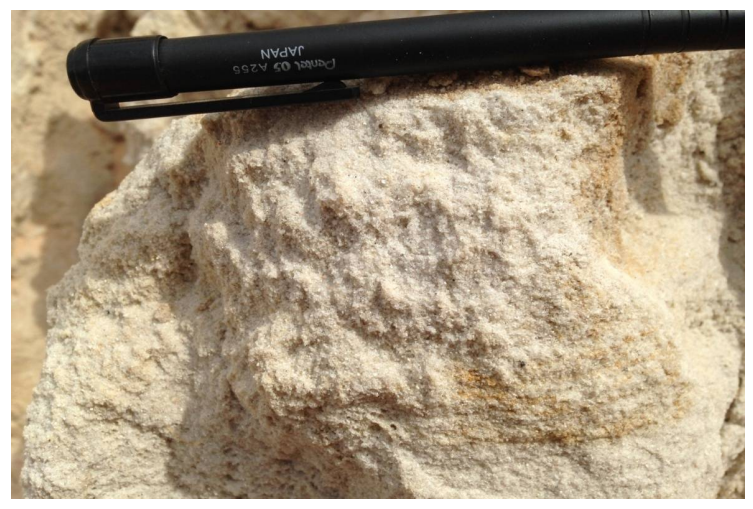

Fig. 4b. Early Pleistocene quartz sand corresponding to regressive phase $\left(\mathrm{Q}_{1}{ }^{1}\right)$ in Suoi Tien (Mui Ne) [Photo by Nguyen Van Tuan, (1916)]

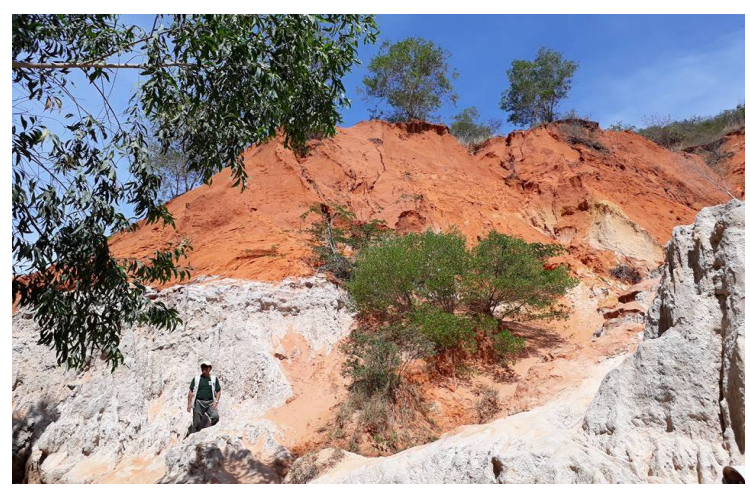

Fig. 4c. Exposure of sandy formation in Suoi Tien (Mui Ne): (1) Gray-white sand (bottom) of sandy barrier bar, with age $>204 \mathrm{ka}\left(\mathrm{Q}_{1}{ }^{2 \mathrm{a}}\right)$;

(2) Red sand (covered) originated from coastal sand dunes $171 \mathrm{ka}\left(\mathrm{Q}_{1}{ }^{2 \mathrm{~b}}\right)$; and (3) Red sand originated from $50 \mathrm{ka}$ wind $\left(\mathrm{Q}_{1}{ }^{3 \mathrm{~b}}\right)$

The section in Chi Cong: This section overlying directly on granite is a $14 \mathrm{~m}$ thick sandy formation with composition and colour changing from the bottom up. Layer 1 consists of medium to fine-grained, $2-3 \mathrm{~m}$ thick, well bonded white sand the upper part is reddish brown sand containing half round grinding tektite and ending with red, homogeneous sand at the height of $5.1 \mathrm{~m}$. Layer 2 consists of $8.5 \mathrm{~m}$ thick red sand, with granularity ranging from coarse to fine $(0.39 \mathrm{~mm}$ to $0.22 \mathrm{~mm})$ grain of second sand layer of the Middle Pleistocene $\left(\mathrm{Q}_{1}{ }^{2 \mathrm{~b}}\right)$. The surface of this sand layer is laterization which is to form clotted solid reddish sandy aggregates which result from bonding in $\mathrm{Fe}_{2} \mathrm{O}_{3}$ with quartz particles. Layer 3 consists of yellow sand distributed on a $16 \mathrm{~m}$ platform with a thickness of $2.5-3.5 \mathrm{~m}$ covered by the abrasive section of reddish lateritic sand. They have the early Late Pleistocene marine origin $\left(\mathrm{mQ}_{2}{ }^{3 \mathrm{a}}\right)$ (fig. 5). The overlap of the coastal sand generations has created three inadequate sedimentary cycles. Quaternary sediment in Vietnam is divided into five sedimentary cycles, each consists of a sequence of sediments. Similar to the section at Phan Thiet airport, each sequence (or sand cycle) consists of three sedimetary parts: The lower part is windy sand (mv), the middle is coastal sand $(\mathrm{m})$ and the upper is aeolian sand (mv). 


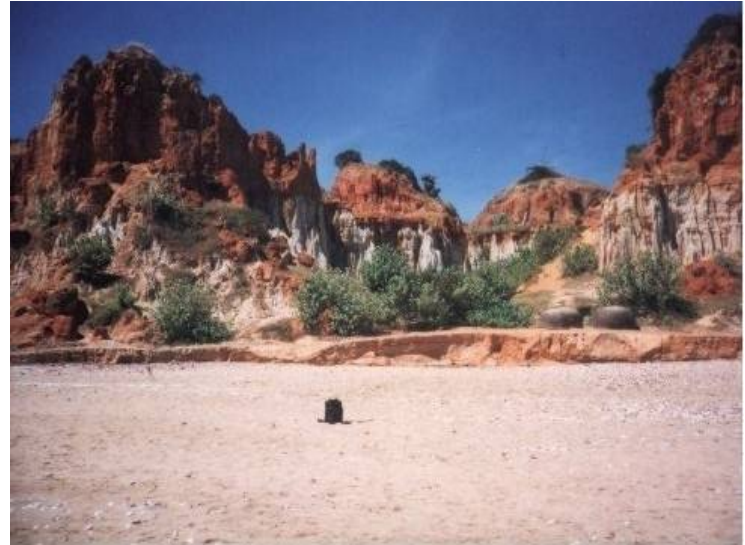

Fig. 5. Section of sediment in Chi Cong: (1)

The lower part is white sand of coastal sandbar, $181 \mathrm{ka}\left(\mathrm{Q}_{1}{ }^{2 \mathrm{a}}\right)$; (2) The red sand in upper layer consists of two layers: Sandy barrier bar, $130 \mathrm{ka}\left(\mathrm{Q}_{1}{ }^{2 \mathrm{~b}}\right)$ and (3) aeolian sand dunes,70 ka $\left(\mathrm{Q}_{1}{ }^{3 \mathrm{a}}\right)$ [Photo by Tran Nghi, (1998)]

\begin{tabular}{|c|c|c|c|c|c|c|}
\hline \multicolumn{2}{|c|}{ Geological age } & \multirow{2}{*}{ 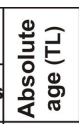 } & \multirow{2}{*}{ Lithology } & \multirow{2}{*}{ 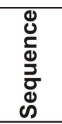 } & \multirow{2}{*}{ Rhythm } & \multirow{2}{*}{ Sea level } \\
\hline Formation & Symbols & & & & & \\
\hline $\begin{array}{l}\text { The late Late } \\
\text { Pleistocene } \\
\text { - Holocene }\end{array}$ & $\begin{array}{l}Q_{1}^{3 b}- \\
Q_{2}\end{array}$ & $\begin{array}{l}19 \pm 30 \\
71 \pm 50\end{array}$ & & $\mathrm{Sq}_{5}$ & V & \\
\hline $\begin{array}{l}\text { The early } \\
\text { Late } \\
\text { Pleistocene }\end{array}$ & $Q_{1}^{3 a}$ & $|121 \pm 60|$ & 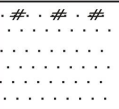 & $\mathrm{Sq}_{4}$ & IV & \\
\hline $\begin{array}{l}\text { The late } \\
\text { Middle } \\
\text { Pleistocene }\end{array}$ & $\mathrm{Q}_{1}{ }^{2 b}$ & $181 \pm 70$ & & $\mathrm{Sq}_{3}$ & III & \\
\hline $\begin{array}{l}\text { The early } \\
\text { Middle } \\
\text { Pleistocene }\end{array}$ & $\mathrm{Q}_{1}{ }^{2 a}$ & $\begin{array}{l}>204 \\
\pm 50\end{array}$ & 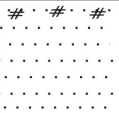 & $\mathrm{Sq}_{2}$ & II & \\
\hline $\begin{array}{c}\text { Early } \\
\text { Pleistocene }\end{array}$ & $\mathrm{Q}_{1}{ }^{1}$ & 700Ka & 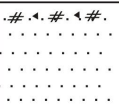 & $\mathrm{Sq}_{1}$ & 1 & \\
\hline
\end{tabular}

Fig. 6. Sequence stratigraphic column of coastal Quaternary sandy formation of Binh Thuan

If separating the colour of the red sand out of the formation mechanism, the history of geological development and climate conditions, it is impossible to understand the nature and principle of red sand. In other words, the red color of sand is a function of a series of variables such as the combination of weather permeability factors, regression; terrain of hills and gentle slopes; Groundwater and surface water. All four of these conditions are closely interrelated and define pair relations as follows:

Regressions occur during the ice age and also correspond to the tectonic phase on the inland. Therefore, in the Phan Thiet sandy area, there is almost only sand dune due to the wind, which is characteristic of marine sediments. The sand dunes have wavy terrace hills and sand dunes have been created in the sea phase before. It means sand dunes have been divided, eroded, decreased and elevated in altitude due to wind at the same time in other locations, creating a weathering pebble in the process, they have not been submerged again due to activity of groundwater and surface water.

We can visualize the terrain of sand dunes during the rising tectonic phase, as the sea level rise and fall are similar to low hills in the midland, suitable permeable weathering mechanism. The current red sand terrain in Luy, Tuy Phong, Phan Thiet,... is the result of a strong tectonic formation in Quaternary, creating a hierarchical rule that corresponds to the abrasive deck accumulation in the upstream area of Mao, Gia Le and Muong Man rivers (fig. 7). Based on altitude and absolute age of red sand, the rate of artificial regeneration can be calculated according to the formula: $H=(h-$ $\left.h_{\mathrm{o}}\right) / T$. In which: $H$ is the actual altitude (adjusted); $h$ is the absolute altitude; $T$ is the formation time, is the sea level rise. The results show that the average lifting speed in Quaternary in Phan Thiet is $1.2 \mathrm{~mm} /$ year.

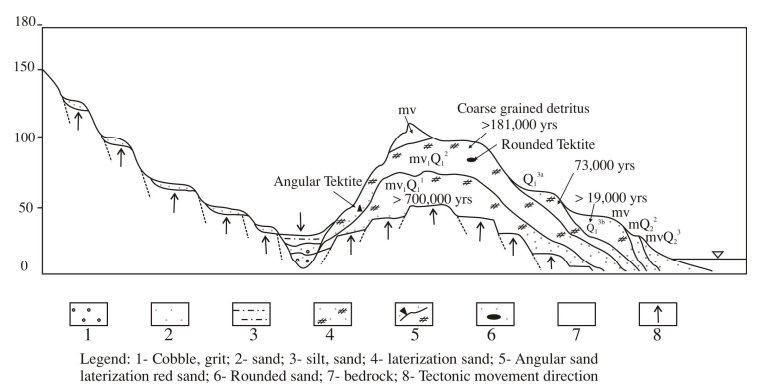

Fig. 7. Schematic diagram of the relationship between depositional abrasive terraces and sand dune systems in Phan Thiet coastal zone

Ancient climate is an important chemical weathering factor, but hot and dry weather 
mixed with tropical rain of Phan Thiet is the only unique direct cause in Vietnam to create the red colour of quartz sand. In the summer in Phan Thiet, the sand is heated severely, the amount of water in sand and water in the iron glue $\left(\mathrm{Fe}_{2} \mathrm{O}_{3} \cdot \mathrm{nH}_{2} \mathrm{O}\right)$ is deposited in the clay particles $(<0.01 \mathrm{~mm})$ and the iron glue that is covered with quartzite particles totally vaporises but is not completely compensated because of the very dry, non-tropical humid characteristics but tropical dry. It is the secret that limonite (yellow) turns into hematite (red wine) which exists in the form of soil and filaments (table 1). It can be easily agreed that the primordial colour of the Pleistocene sand of Phan Thiet is white in accordance with the principle of basic geology and the red color is associated with the weathering phase and it is the secondary colour.

Table 1. Composite parameters of Phan Thiet red sand sediments

\begin{tabular}{|c|c|c|c|c|c|c|c|c|c|c|c|c|c|}
\hline $\begin{array}{c}\text { Environ } \\
\text { ment }\end{array}$ & Age & Lithology & 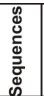 & $\frac{0}{0}$ & Md & So & Ro & Sf & 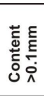 & 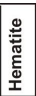 & Q & $\mathrm{SiO}_{2}$ & $\begin{array}{l}\text { Glacial } \\
\text { cycles }\end{array}$ \\
\hline $\begin{array}{c}\mathrm{mv} \\
\mathrm{m} \\
\mathrm{mv}\end{array}$ & $\begin{array}{l}\mathrm{Q}_{1}{ }^{3 \mathrm{~b}} \\
\overline{\mathrm{Q}}_{2}\end{array}$ & \begin{tabular}{ll}
$\cdots$ \\
$\because \cdots$ \\
\hdashline
\end{tabular} & $\mathrm{Sq}_{5}$ & & 0.1 & 1.2 & 0.7 & 0.8 & 8 & & 98 & 1.5 & $\begin{array}{c}\text { Flandri } \\
\uparrow \\
\text { Wurm 2 }\end{array}$ \\
\hline $\begin{array}{c}\mathrm{mv} \\
\mathrm{m} \\
\mathrm{mv}\end{array}$ & $Q_{1}{ }^{3 a}$ & \begin{tabular}{|l|}
$\# \cdot * \# \cdot \#$ \\
$\cdots \cdots \cdots$ \\
$\because \cdots \cdots$ \\
$\because \because \cdots$
\end{tabular} & $\mathrm{Sq}_{4}$ & $y-r$ & 0.15 & 1.3 & 0.6 & 0.7 & 12 & $1-3$ & 95 & 1.5 & W \\
\hline $\begin{array}{c}\mathrm{mv} \\
\mathrm{m} \\
\mathrm{mv}\end{array}$ & $\mathrm{Q}_{1}{ }^{2 \mathrm{~b}}$ & 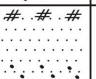 & $\mathrm{Sq}_{3}$ & $y$ & 0.18 & 1.5 & 0.6 & 0.7 & 15 & $5-8$ & 95 & 1.8 & \\
\hline $\begin{array}{c}\mathrm{mv} \\
\mathrm{m} \\
\mathrm{mv}\end{array}$ & $\mathrm{Q}_{1}{ }^{2 \mathrm{a}}$ & 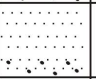 & $\mathrm{Sq}_{2}$ & $y-r$ & 0.18 & 1.5 & 0.5 & 0.7 & 10 & $3-5$ & 93 & 1.5 & \\
\hline $\begin{array}{c}\mathrm{mv} \\
\mathrm{m} \\
\mathrm{a}, \mathrm{m}\end{array}$ & $Q_{1}{ }^{1}$ & 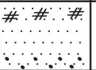 & $\mathrm{Sq}_{1}$ & $y-r$ & 0.25 & 2.5 & 0.3 & 0.6 & 10 & & 93 & 1.5 & Gunz \\
\hline
\end{tabular}

\section{Tidal ecoregion}

The tidal zone consists of upper tidal zone, tidal flat, and sub-tidal flat. Tidal regions are created by tidal activities and waves. Therefore, the major component is quartz sand (> 85\%), which is well-rounded and well-sorted. The upper tidal zone is located on the high tides, created during storm surges. This zone is also known as beach with wide terrains ranging from $50-100 \mathrm{~m}$. The tidal flat is within the boundary of high tide, sloping, with a width of $20-50 \mathrm{~m}$. Hydrodynamic regime governing sedimentation are tides and waves. The subtidal flat is always flooded with relatively steep terrain.
The tidal region of Binh Thuan province is continually encroaching on the mainland due to shore erosion [8]. They have an onlap structure with a backward tile pattern. The closer to the inland is, the younger sediments is, the sediments are replaced continually which causes the stabilization of beach. Therefore, it is the conflict between tourism development and natural disaster that requires disaster mitigation measures to ensure sustainable development [9].

\section{Coastal marine ecosystem (5 - $30 \mathrm{~m}$ water)}

In relation to sea level change, sedimentary evolution and coastal marine morphology (5 $30 \mathrm{~m}$ water) are approached from the geomorphologic topographic view, it is possible to divide the seabed (5 - $30 \mathrm{~m}$ water) into following units: (1) The terrain of seabed $\left(5-25 \mathrm{~m}\right.$ water) tilts $\left(1-20^{\circ}\right)$ under the action of falling waves and dissipating waves, coastal and bottom flows [10]. The sediments are mainly re-granulated and re-deposited from the Flandrian transgressive phase to Late Holocene regressive phase and modern transgressive phase. Therefore, sedimentary composition and particle size are still in cabolism phase and distributed due to continual flow from north to south; (2) The ancient shoreline topography (25-30m water). The ancient terrain of the Late Pleistocene (about 13,000 years) is quite diverse: Wavy, sub-terrain sand dunes running parallel to the shallow gravel and tidal retreats tilting towards the sea [11]. This is the result of the coastal surf zone when the coast has ceased for a long time.

\section{Discussion}

The relationship between the differentiation of ecoregions and the Quaternary geological activities has fluctuated continuously for 1.8 million years up to present.

The four ecoregions are the results of endogenous and exogenous geological processes in the Quaternary and the five regressive and transgressive cycles [12]. Each ecoregion has specific characteristics of topography, geomorphology, sedimentary composition, biodiversity, vegetation cover nature. The narrow plain ecoregion sandwiched 
between the coastal sand dunes and the Truong Son mountains is a result of the fluvial - marine sedimentary process of the Late Holocene regressive phase $\left(\mathrm{Q}_{2}{ }^{3}\right)$. The sand dune ecoregion developed on the lifting structure of the base rock. Endogenous geological processes in the Quaternary developed inheritedly from the Tertiary. The sand dune basements are high rising bedrock formations such as sand barriers that created sandy barrier bars in transgressive phases. After each cycle of forming sand, the structure of the basement shifted to lifting and the inner bays subsided and filled the fluvial - marine sediments. As a result, the sand terraces were raised to $80 \mathrm{~m}$ (Phan Thiet airport), $60 \mathrm{~m}$ (Luy river), $40 \mathrm{~m}$ (Bau Trang). The sand dune ecoregion is a unique geological heritage of the unique red sands of Vietnam that characterizes the land of the red sand highland of an arid region which contains enormous reserves of titanium mineral. The intertidal ecoregion is a sensitive area which constantly changes due to shore erosion. The topographic and geomorphologic features and sedimentary compositions are dominated mainly by the hydrodynamics of coastal wave-cut, splash zones in relation to tidal and coastal currents which are generated by waves and tides. The subterranean basin ecoregion $(5-25 \mathrm{~m})$ is predominantly grit sand and sand well-sorted and well-rounded due to the redistribution of the modern bottom flow of the ancient coastal tide in Flandrian transgression. This ecoregion is the best habitat for bivalves, therefore, it should be considered a biological area of biological resources area. The ancient shoreline ecoregion $(25-30 \mathrm{~m}$ water) in the age of Early-Middle $\left(\mathrm{Q}_{2}{ }^{1-2}\right)$ Holocene was formed by a relatively long coastline during the early Middle Holocene (approximately 13,500 - 13,000 years BP). This ecoregion is rich in titanium mineral sand as it is enriched by coastal waves.

The uplift and subsidence occur rhythmically following five cycles of sea level change due to the effect of five glacial cycles: Gunz/G-M; Mindel/M-R; R/R-W; $\mathrm{W}_{1} / \mathrm{W}_{1}-\mathrm{W}_{2}$ and Flandrian transgression.

\section{CONCLUSION}

The coastal zone of Binh Thuan province has four typical ecoregions:

The Late Holocene plain ecoregion with fluvial - marine origin is distributed between the coastal sand dunes and the Truong Son mountain.

The coastal sand dune ecoregion is $0-150$ $\mathrm{m}$ high.

The tidal ecoregion is $0-5 \mathrm{~m}$ deep.

The bottom sediment ecoregion is 5 25 m deep.

The ancient shoreline ecoregion is 25 $30 \mathrm{~m}$ deep.

The creation of each ecoregion is associated with endogenous and exogenous geological processes. Endogenous geological processes are caused mainly by faults and movement of platforms. Exogenous geological processes are mainly sedimentary processes.

The plain and subterranean bay ecoregion were formed mainly due to subsidence and sedimentary processes in relation to the sea level change in the Holocene.

Sand dune ecoregion is the result of the evolution process of five cycles of sand formation in relation to the five cycles of sea level change in the Quaternary due to the effect of five glacial cycles:

Gunz/G-M: Occurred in the Early Pleistocene $\left(\mathrm{Q}_{1}{ }^{1}\right)$.

Mindel/M-R: Occurred in the early Middle Pleistocene $\left(\mathrm{Q}_{1}{ }^{2 \mathrm{a}}\right)$.

Riss/R-W1: Occurred in the late Middle Pleistocene $\left(\mathrm{Q}_{1}{ }^{2 \mathrm{~b}}\right)$.

Wurm1/W1-W2: occurs in the early Late Pleistocene $\left(\mathrm{Q}_{1}{ }^{3 \mathrm{a}}\right)$.

Wurm2/Flandrian transgression $\left(\mathrm{Q}_{1}{ }^{3 \mathrm{~b}}-\mathrm{Q}_{2}\right)$.

Acknowledgment: The paper was completed by the help of the Vietnam Environment Administration, the Department of Natural Resources and Environment of Binh Thuan province, the VNU University of Sciences during the field study, data and document 
collecting process. On this occasion, the authors would like to thank for the precious helps of above mentioned organizations.

\section{REFERENCES}

1. Department of Construction of Binh Thuan province, 2010. Master plan for daily-life water supply in Binh Thuan province up to 2020.

2. The Department of Construction of Binh Thuan province, 2010. The general overview of construction planning of Binh Thuan province until 2030.

3. Tran Nghi et al., 1996. Evolution of Central Coastal Sand Formation in Interactions with Changes in Sea Levels in Quaternary, Proceedings of Geosciences and Marine Geomatics, 2. Hanoi. Pp. 130-138.

4. Tran Nghi, Nguyen Bieu, Bui Cong Que, 1996. Distribution regulation of the marine placers in Quaternary formations Vietnam. Journal of Geology, 237, 11-12.

5. Tran Nghi et al., 1998. Environment and forming mechanism of Phan Thiet red sands. Journal of Geology, 245, 10-20.

6. Murray-Wallace, C. V., Jones, B. G., Nghi, T., Price, D. M., Van Vinh, V., Tinh, T. N., and Nanson, G. C., 2002. Thermoluminescence ages for a reworked coastal barrier, southeastern Vietnam: a preliminary report. Journal of Asian Earth Sciences, 20(5), 535-548.

7. Nguyen Van Thuan, Tran Van Thao, 2008. Discovery of industrial titanium-zircon placer in the red sand of the Phan Thiet Formation in the coastal zone of South Central Coast. Journal of Geology, 308, 18-24.

8. Nguyen Van $\mathrm{Cu}$, Pham Huy Tien, 2001. Study on coastal landslide prevention in Central Vietnam (from Thanh Hoa to Binh Thuan). Institute of Geography, VAST, Report on research results, Hanoi.

9. Tran Van Y et al., 2005. Study on developing a comprehensive solution for rational use of Central coastal sandbanks from Quang Binh to Binh Thuan. Final Report KC.08.21, Institute of Geography, VAST, Hanoi.

10. Tran Duc Thanh, 2010. Some principal issues on integrated coastal zone management in Vietnam. Journal of Marine Science and Technology, 10(1), 81-96.

11. Nguyen Dinh Hoe ,2007. Environment and Sustainable Development. Education Publishing House, Hanoi.

12. Pham Ngoc Dang, 2011. Sustainable development of environment in Vietnam: achievements, current challenges and direction in the coming time. Journal of the Environment, Hanoi. 